\title{
Prevalence of Pathogenic Bacteria Isolated from Two Selected Salad Vegetables and Antibiogram Profile of Klebsiella spp.
}

\author{
Sumon Kumar Kundu and Md. Tanvir Islam* \\ Department of Microbiology, Jessore University of Science \& Technology, \\ Jessore -7408, Bangladesh. \\ *Corresponding author and Email: mt.islam@just.edu.bd
}

Received: 19 March $2015 \quad$ Accepted: 06 June 2015

\begin{abstract}
The study was conducted to examine microbiological quality of raw salad vegetables of Jessore city of Bangladesh. Fourteen samples of two types of vegetables which are commonly used for salad eg. Tomato (Lycopersicum esculentum) and Cucumber (Cucumis sativus) were collected from different local markets of Jessore City and their bacteriological attributes were investigated using routine methods. All the vegetables were highly contaminated with coliforms and fecal coliforms. Range of Total Viable Count were $11 \times 10^{6} \mathrm{CFU} / \mathrm{g}$ to $20 \times 10^{7} \mathrm{CFU} / \mathrm{g}$ for tomato and $12 \times 10^{5} \mathrm{CFU} / \mathrm{g}$ to $24 \times 10^{7}$ $\mathrm{CFU} / \mathrm{g}$ for cucumber, Total Coliform Count were $11 \times 10^{4} \mathrm{CFU} / \mathrm{g}$ to $2 \times 10^{6} \mathrm{CFU} / \mathrm{g}$ for tomato and $10.2 \times 10^{3} \mathrm{CFU} / \mathrm{g}$ to $60 \times 10^{4} \mathrm{CFU} / \mathrm{g}$ for cucumber and Total Staphyllococcal Count were $11 \times 10^{4} \mathrm{CFU} / \mathrm{g}$ to $25 \times 10^{6} \mathrm{CFU} / \mathrm{g}$ for tomato and $10 \times 10^{4} \mathrm{CFU} / \mathrm{g}$ to $50 \times 10^{6} \mathrm{CFU} / \mathrm{g}$ for cucumber. Total coliforms were identified as Escherichia coli, Klebsiella spp., Enterobacter spp., Citrobacter spp. and Shigella spp. Antibiogram was conducted with twelve different antibiotics for some randomly selected pure colonies of Klebsiella spp. Multidrug resistance was observed in $90 \%$ isolates with resistance from two to six antibiotics. Hygienic practices should be followed in handling the vegetables in local markets and vegetables might have an important role as a source of antibiotic resistant bacteria.

Keywords: Salad vegetables, Coliforms, Microbiological quality, Antibiotic resistance, Multidrug resistance, Jessore city

\section{Introduction}

Salad is a food condiment and serves a major part of our food habit. Usually raw vegetables are used as salad items. Matter of facts, these raw vegetables harbor many pathogenic microorganisms. Many researchers claimed that vegetables could be associated with outbreaks of foodborne diseases. The outbreaks can differ in size from a few persons to many thousands (Halablab et al., 2011). Common pathogens found in vegetable (salad) include; Staphylococcus aureus, Enterobacter spp.,

Klebsiella spp., Escherichia coli, Salmonella typhi, Serratia spp., Pseudomonas aeruginosa, Yersinia enterocolitica, Listeria monocytogenes, Aeromonas hydrophila and Shigella sonnei (Poorna and Randhir, 2001). Contamination of vegetables may occur at all stages during pre and post-harvest techniques (Halablab et al., 2011). Use of untreated waste water and manure as fertilizers for the production of vegetables is a major contributing factor to contamination (Olayemi, 2007). Other possible sources of microorganisms include soil, feces (human and animal origin), animals (including insects and
\end{abstract}


birds), handling of the product, harvesting and processing equipment and transport (Johannessen et al., 2002). In developing countries, foodborne illnesses caused by contaminated vegetables are frequent and in some areas they cause a large proportion of illness. However, due to lack of foodborne disease investigation and surveillance, most outbreaks go unrevealed and the scientific literature reports only on very few outbreaks.

In recent decades, antimicrobial resistance and reduced sensitivity in pathogenic bacteria have become a major public health problem in many countries (Rabbi et al., 2011). Many studies have reported the presence of multidrug resistant bacteria in different types of food (Nipa et al., 2011; Osibote et al., 2014). Drug resistance is spreading day by day mainly due to the overuse of antibiotics, incomplete and under use of medications and widespread practice of feeding livestock with low levels of antibiotics to promote growth (Sultana et al., 2014). In this case, raw salad vegetables could serve as vehicles of antimicrobial resistance to pathogenic bacteria from environments to humans and from one place to another. Considering these facts, the current study was undertaken to assess the microbiological quality of two vegetables commonly used as salad from different local markets of Jessore city by detecting the overall microbial load, identification of the pathogenic microorganisms and evaluation of the antimicrobial susceptibility test of isolated specific pathogen.

\section{Materials and Methods}

\subsection{Collection of samples}

A total of fourteen samples of tomato and cucumber were collected from different randomly selected local markets of Jessore city. The samples were collected during the period of January-June, 2014. All samples were collected in sterile polythene bag in an insulated box with ice to maintain a temperature ranging from 4 to 6 ${ }^{\circ} \mathrm{C}$.

\subsection{Sample processing}

From each sample, $20 \mathrm{~g}$ was aseptically weighed and ground to paste using mortar and pestle and later transferred into $100 \mathrm{ml}$ conical flasks containing $80 \mathrm{ml}$ sterile saline water under laminar air flow to prepare stock solution. Sterile serial dilution was made upto $10^{-6}$ using sterile distilled water as diluents.

\subsection{Isolation and Enumeration of total bacteria} Isolation and enumeration of bacteria were done by growing them on selective and non-selective media such as nutrient agar for total viable count (TVC), MacConkey agar for total coliform count (TCC) and Mannitol salt agar (MSA) for total staphylococcal count (TSC). For bacterial enumeration, spread plate method was used to determine the number of colony forming units (CFU/g).

\subsection{Identification of coliforms}

For presumptive identification of coliform bacteria isolates were randomly selected for major biochemical tests such as Triple Sugar Iron, Motility Indole Urease, Methyl Red, Voges-Proskaur, and Citrate Utilization test. The tests were performed using conventional methods. Isolates were then identified according to Bergey's manual of determinative bacteriology (Krieg and Holt, 1984).

\subsection{Antimicrobial susceptibility testing}

Antimicrobial susceptibility of thirty isolates of Klebsiella spp. were performed by the disk diffusion technique using guidelines established by Bauer et al. (1966). A total of 12 antibiotic discs (Oxoid Ltd., Basingstoke, Hampshire, UK) comprising of amoxycillin $(10 \mu \mathrm{g})$, ceftriaxone $(30 \mu \mathrm{g})$, imipenem $(10 \mu \mathrm{g})$, ciprofloxacin $(5 \mu \mathrm{g})$, streptomycin $(10 \mu \mathrm{g})$, tetracycline $(30 \mu \mathrm{g})$, gentamicin $(10 \mu \mathrm{g})$, nalidixic acid $(30 \mu \mathrm{g})$, chloramphenicol $(30 \mu \mathrm{g})$, trimethoprimsulfamethoxazole $(25 \mu \mathrm{g})$, norfloxacin $(10 \mu \mathrm{g})$, and erythromycin $(15 \mu \mathrm{g})$ were used. Within 15 min of the application of the discs, the plates were inverted and incubated at $37^{\circ} \mathrm{C}$. After incubation of 16-18 hours, the plates were examined, and the diameters of the zone of 
inhibition were measured. The raw data were interpreted based on the available CLSI (Clinical and Laboratory Standards Institute) data and zone diameter interpretive standards.

\section{Results and Discussion}

\subsection{Colony morphology, phenotypic and biochemical traits of the isolates}

After 24 hours of incubation, typical pink, circular, convex colonies on MacConkey agar and light yellow colonies on Mannitol salt agar were primarily considered as coliforms and Staphylococcus spp., respectively. Isolates from MacConkey were observed as Gram negative, single, short rods which represent the typical properties of coliforms and isolates from MSA were Gram positive in a cluster arrangement which were typical for Staphylococcus spp. Based on the biochemical characteristics, isolates were confirmed as Escherichia coli, Klebsiella spp., Enterobacter spp., Citrobacter spp., Shigella spp. and Staphylococcus spp. (Table 1).

\subsection{Bacterial load (CFU/g) of fresh salad vegetables}

Total bacteria isolated from tomato and cucumber are listed in Table 2. The highest total viable count for tomato was $20 \times 10^{7} \mathrm{CFU} / \mathrm{g}$ while the lowest was $11 \times 10^{6} \mathrm{CFU} / \mathrm{g}$. On the other hand, the highest total viable count for cucumber was $24 \times 10^{7} \mathrm{CFU} / \mathrm{g}$ and the lowest was $12 \times 10^{5}$ $\mathrm{CFU} / \mathrm{g}$. Unlike tomatoes, cucumbers are rarely contaminated by soil pathogens as they do not come in contact with the soil. So, contamination with pathogens could be due to poor hygienic practices by the handlers and sellers. The present results support the findings of Adebayo-Tayo et al. (2012) and Adeshina et al. (2012) who found that the total bacterial count in vegetable salads ranged from $1.28 \times 10^{6}$ to $3.20 \times 10^{6} \mathrm{CFU} / \mathrm{g}$. Nawas et al. (2012) counted $9.0 \times 10^{4} \mathrm{CFU} / \mathrm{g}$ to $3.8 \times 10^{5} \mathrm{CFU} / \mathrm{g}$ total viable count from tomato and $5.5 \times 10^{4} \mathrm{CFU} / \mathrm{g}$ to $1.9 \times 10^{6} \mathrm{CFU} / \mathrm{g}$ from cucumber. These values are were comparatively lower than those of the present study.Results of our study partially supports the findings of Uzeh et al. (2009) who found $5.9 \times 10^{6} \mathrm{CFU} / \mathrm{g}$ from open markets and $2.6 \times 10^{4} \mathrm{CFU} / \mathrm{g}$ from fast food outlets.

Table 1. Results of biochemical tests of the bacterial isolates isolated from salad vegetables

\begin{tabular}{|c|c|c|c|c|c|c|c|c|c|c|c|}
\hline \multirow{2}{*}{ Isolate No. } & \multicolumn{4}{|c|}{ TSI test } & \multirow{2}{*}{$\begin{array}{l}\stackrel{\varpi}{\Xi} \\
己\end{array}$} & \multicolumn{3}{|c|}{ MIU test } & \multirow[b]{2}{*}{$\stackrel{\mathscr{z}}{\Sigma}$} & \multirow[b]{2}{*}{ 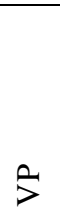 } & \multirow{2}{*}{$\begin{array}{c}\text { Probable } \\
\text { organisms }\end{array}$} \\
\hline & Е & $\frac{\vec{\Xi}}{\text { ज }}$ & 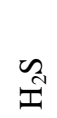 & $\tilde{\Xi}$ & & 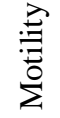 & $\frac{0}{0}$ & 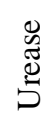 & & & \\
\hline $\begin{array}{l}1,2,5,6,7,8,10,12,15, \\
17,18,19,22,23,25,27, \\
28,30,33,36,37,40,42, \\
43,45,46,52,55,56,57, \\
58,59,60 .\end{array}$ & A & A & - & + & + & - & - & + & + & - & Klebsiella spp. \\
\hline $\begin{array}{l}3,11,21,24,26,39,47, \\
48 .\end{array}$ & $\mathrm{A}$ & $\mathrm{A}$ & - & + & + & + & - & - & - & + & $\begin{array}{l}\text { Enterobacter } \\
\text { spp. }\end{array}$ \\
\hline $14,29,41,44,49,50,51$. & $\mathrm{A}$ & $\mathrm{K}$ & - & - & - & - & - & - & + & - & Shigella spp. \\
\hline $9,16,31,34,35$ & $\mathrm{~A}$ & $\mathrm{~K}$ & - & + & + & + & - & + & + & - & Citrobacte spp. \\
\hline $14,29,41,44,49,50,51$ & $\mathrm{~A}$ & $\mathrm{~K}$ & - & + & - & + & + & - & + & - & E. coli \\
\hline
\end{tabular}


In the present study, TVC were found higher compared to other studies, which might have resulted from relatively poor hygienic condition. However, our findings study differs from the findings of Osamwonyi et al. (2013), who isolated $1.46 \times 10^{4}$ to $2.80 \times 10^{4} \mathrm{CFU} / \mathrm{g}$ from vegetable salad and the microbial load was indicative of the fact that the microenvironments within these salads provided favorable conditions for the growth and proliferation of diverse groups of bacteria.

The coliform count was also high in all samples (Table 2). Range of total coliform count of Tomato was $11 \times 10^{4} \mathrm{CFU} / \mathrm{g}$ to $27 \times 10^{6} \mathrm{CFU} / \mathrm{g}$ and $10.2 \times 10^{3} \mathrm{CFU} / \mathrm{g}$ to $60 \times 10^{4} \mathrm{CFU} / \mathrm{g}$ for cucumber. Higher prevalence of coliform bacteria was reported by many workers. In Turkey, Hasan et al. (2006) showed the presence of E. coli (1-3.8 $\mathrm{CFU} / \mathrm{g}$ ) in raw eaten vegetables. In India, the salad vegetables were contaminated by coliforms (Rajvanshi, 2010). The findings of the present study is strongly supported by Adebayo-Tayo et al. (2012) who found the total coliform count in vegetable salads ranging from $2.35 \times 10^{6}$ to 3.28 x $10^{6} \mathrm{CFU} / \mathrm{g}$. The finding of the present study findings also supports with the findings of Rabbi et al. (2011), Osamwonyi et al. (2013) and Nipa et al. (2011) tested different samples of salad vegetables and observed that the differences between the mean bacterial counts were statistically insignificant $(\mathrm{P}>0.01)$. The presence of $E$. coli in raw salad vegetables analyzed is a common indicator of fecal contamination. E. coli are part of the normal flora of the human gastrointestinal tract. Some strains of E. coli have been related to diahorrea, gastro-enteritis and urinary tract infections (Hassan et al., 2006). The samples were also found to contain gram negative bacteria like, Klebsiella spp., Enterobacter spp., Citrobacter spp. and Shigella spp. which are potential pathogens and thus pose a serious threat to public health. Klebsiella spp. is second only to E. coli as a human urinary tract pathogen. It is familiar to the environment and can be cultured from soil, water and vegetables when consumed raw as in salads. The isolation of coliforms from salad vegetables was not unexpected since water used to irrigate the vegetable crops and the manure used as fertilizer are reported to contain coliforms and other enteric bacteria (Gagliardi and Karns, 2000).

Table 2. Bacterial load (CFU/g) of fresh salad vegetables

\begin{tabular}{ccccc}
\hline $\begin{array}{c}\text { Sample } \\
\text { no. }\end{array}$ & $\begin{array}{c}\text { Types of Salad } \\
\text { Vegetables. }\end{array}$ & $\begin{array}{c}\text { Total Viable Count } \\
\text { (TVC) }\end{array}$ & $\begin{array}{c}\text { Total Coliform } \\
\text { Count (TCC) }\end{array}$ & $\begin{array}{c}\text { Total Staphyllococcal } \\
\text { Count (TSC) }\end{array}$ \\
\hline 1. & Tomato & $10.2 \times 10^{6}$ & $12 \times 10^{4}$ & $50 \times 10^{4}$ \\
2. & Tomato & $11 \times 10^{6}$ & $10 \times 10^{4}$ & $12 \times 10^{4}$ \\
3. & Tomato & $20 \times 10^{6}$ & $27 \times 10^{6}$ & $15 \times 10^{6}$ \\
4. & Tomato & $21 \times 10^{6}$ & $17 \times 10^{5}$ & $25 \times 10^{6}$ \\
5. & Tomato & $20 \times 10^{7}$ & $26 \times 10^{5}$ & $17 \times 10^{5}$ \\
6. & Tomato & $17 \times 10^{6}$ & $11 \times 10^{4}$ & $12 \times 10^{4}$ \\
7. & Tomato & $13 \times 10^{6}$ & $10 \times 10^{5}$ & $11 \times 10^{4}$ \\
8. & Cucumber & $26 \times 10^{5}$ & $17 \times 10^{4}$ & $15 \times 10^{6}$ \\
9. & Cucumber & $12 \times 10^{5}$ & $10.2 \times 10^{3}$ & $10 \times 10^{4}$ \\
10. & Cucumber & $25 \times 10^{5}$ & $10 \times 10^{4}$ & $25 \times 10^{4}$ \\
11. & Cucumber & $80 \times 10^{5}$ & $17 \times 10^{4}$ & $10 \times 10^{5}$ \\
12. & Cucumber & $25 \times 10^{5}$ & $30 \times 10^{4}$ & $50 \times 10^{6}$ \\
13. & Cucumber & $40 \times 10^{5}$ & $50 \times 10^{4}$ & $50 \times 10^{6}$ \\
14. & Cucumber & $24 \times 10^{7}$ & $60 \times 10^{4}$ & $11 \times 10^{4}$ \\
\hline
\end{tabular}


Table 3. Antibiotic sensitivity of isolated Klebsiella spp. from salad vegetables

\begin{tabular}{|c|c|c|c|c|c|c|c|c|c|c|c|c|}
\hline \multirow{3}{*}{$\begin{array}{c}\text { Klebsiella } \\
\text { spp.(Isolate } \\
\text { no.) }\end{array}$} & \multicolumn{12}{|c|}{ Zones of inhibition (mm) } \\
\hline & \multicolumn{3}{|c|}{$\begin{array}{c}\text { G-I (Cell wall } \\
\text { synthesis inhibitor) }\end{array}$} & \multicolumn{5}{|c|}{$\begin{array}{l}\text { G-II (Protein synthesis } \\
\text { inhibitor) }\end{array}$} & \multicolumn{4}{|c|}{$\begin{array}{l}\text { G-III (Nucleic acid } \\
\text { synthesis inhibitor) }\end{array}$} \\
\hline & AML & $\mathrm{CRO}$ & IPM & CIP & $\mathrm{S}$ & $\mathrm{TE}$ & $\mathrm{CN}$ & $\mathrm{E}$ & NA & $\mathrm{C}$ & SXT & NOR \\
\hline 1. & 16 & 32 & 21 & 34 & 13 & 17 & 16 & $\mathrm{R}$ & 22 & 22 & 21 & 32 \\
\hline 5. & 16 & 30 & 21 & 35 & 13 & 15 & 17 & $\mathrm{R}$ & 21 & 24 & 21 & 35 \\
\hline 6. & $\mathrm{R}$ & 25 & 20 & 31 & 13 & 16 & 17 & $\mathrm{R}$ & 20 & 20 & 22 & 30 \\
\hline 10. & $\mathrm{R}$ & $\mathrm{R}$ & 21 & 32 & 14 & 16 & 17 & $\mathrm{R}$ & 20 & 21 & 25 & 32 \\
\hline 12. & $\mathrm{R}$ & 29 & 24 & 28 & 15 & 17 & 18 & $\mathrm{R}$ & 20 & 23 & 21 & 25 \\
\hline 15. & $\mathrm{R}$ & 27 & 22 & 27 & 16 & 18 & 17 & $\mathrm{R}$ & 18 & 24 & 21 & 25 \\
\hline 17. & 12 & $\mathrm{R}$ & 22 & 22 & 17 & 16 & 20 & 17 & 15 & $\mathrm{R}$ & 20 & 17 \\
\hline 18. & 17 & 28 & 21 & 26 & 15 & 17 & 16 & $\mathrm{R}$ & $\mathrm{R}$ & 17 & 25 & 13 \\
\hline 19. & 17 & 28 & 22 & 33 & 15 & 17 & 17 & $\mathrm{R}$ & $\mathrm{R}$ & 22 & 22 & 31 \\
\hline 22. & 16 & $\mathrm{R}$ & 30 & 23 & 17 & 18 & 20 & $\mathrm{R}$ & 16 & 25 & 23 & 18 \\
\hline 23. & $\mathrm{R}$ & $\mathrm{R}$ & 23 & 22 & 16 & 18 & 20 & $\mathrm{R}$ & 17 & 26 & 21 & 21 \\
\hline 25. & 29 & 25 & 23 & 25 & 16 & 20 & 18 & $\mathrm{R}$ & 15 & 23 & 12 & 21 \\
\hline 27. & $\mathrm{R}$ & $\mathrm{R}$ & 19 & 27 & 15 & $\mathrm{R}$ & 17 & 15 & 16 & 18 & 21 & 25 \\
\hline 28. & $\mathrm{R}$ & $\mathrm{R}$ & 21 & 26 & 15 & $\mathrm{R}$ & 16 & $\mathrm{R}$ & 20 & 19 & 21 & 25 \\
\hline 30. & $\mathrm{R}$ & $\mathrm{R}$ & 19 & 25 & $\mathrm{R}$ & $\mathrm{R}$ & 15 & $\mathrm{R}$ & 18 & 18 & 17 & 25 \\
\hline 33. & $\mathrm{R}$ & $\mathrm{R}$ & 21 & 30 & 13 & $\mathrm{R}$ & 20 & $\mathrm{R}$ & $\mathrm{R}$ & 13 & $\mathrm{R}$ & 31 \\
\hline 36. & $\mathrm{R}$ & $\mathrm{R}$ & 35 & 26 & 16 & 21 & 20 & $\mathrm{R}$ & 15 & $\mathrm{R}$ & 20 & 26 \\
\hline 37. & 15 & $\mathrm{R}$ & 26 & 27 & 16 & $\mathrm{R}$ & 20 & $\mathrm{R}$ & 22 & 15 & $\mathrm{R}$ & 25 \\
\hline 40. & $\mathrm{R}$ & $\mathrm{R}$ & 28 & 23 & 20 & 20 & 20 & $\mathrm{R}$ & 16 & 22 & $\mathrm{R}$ & 21 \\
\hline 42. & 12 & $\mathrm{R}$ & 20 & 30 & 12 & 16 & 20 & $\mathrm{R}$ & 18 & 21 & 20 & 20 \\
\hline 43. & 15 & $\mathrm{R}$ & 30 & 24 & 16 & 24 & 21 & $\mathrm{R}$ & 16 & 22 & 25 & 25 \\
\hline 45. & $\mathrm{R}$ & $\mathrm{R}$ & 19 & 30 & 15 & 16 & 18 & $\mathrm{R}$ & 18 & 20 & 16 & 30 \\
\hline 46. & $\mathrm{R}$ & $\mathrm{R}$ & 24 & 21 & 16 & $\mathrm{R}$ & 19 & $\mathrm{R}$ & $\mathrm{R}$ & 20 & $\mathrm{R}$ & 20 \\
\hline 52. & $\mathrm{R}$ & $\mathrm{R}$ & 29 & 23 & 16 & 16 & 18 & $\mathrm{R}$ & 16 & 20 & 19 & 17 \\
\hline 55. & 12 & $\mathrm{R}$ & 30 & 26 & 23 & 19 & 26 & 26 & 17 & 22 & $\mathrm{R}$ & 24 \\
\hline 56. & $\mathrm{R}$ & $\mathrm{R}$ & 21 & 22 & 17 & $\mathrm{R}$ & 21 & 19 & $\mathrm{R}$ & 20 & $\mathrm{R}$ & 21 \\
\hline 57. & 14 & $\mathrm{R}$ & 32 & 25 & 20 & 15 & 23 & $\mathrm{R}$ & 20 & 22 & $\mathrm{R}$ & 23 \\
\hline 58. & $\mathrm{R}$ & $\mathrm{R}$ & 18 & 23 & 16 & 17 & 18 & $\mathrm{R}$ & 17 & 20 & 20 & 21 \\
\hline 59. & $\mathrm{R}$ & $\mathrm{R}$ & 28 & 25 & 17 & 17 & 22 & $\mathrm{R}$ & 15 & 20 & $\mathrm{R}$ & 24 \\
\hline 60. & $\mathrm{R}$ & $\mathrm{R}$ & 30 & 22 & 15 & $\mathrm{R}$ & 18 & $\mathrm{R}$ & 15 & 20 & 16 & 25 \\
\hline
\end{tabular}

$\mathrm{AML}=$ Amoxycillin $(10 \mu \mathrm{g}), \mathrm{CRO}=$ Ceftriaxone $(30 \mu \mathrm{g}), \mathrm{IPM}=\operatorname{Imipenem}(10 \mu \mathrm{g}), \mathrm{CIP}=\mathrm{Ciprofloxacin}(5 \mu \mathrm{g})$, $\mathrm{S}=$ Streptomycin $(10 \mu \mathrm{g}), \mathrm{TE}=$ Tetracycline $(30 \mu \mathrm{g}), \mathrm{CN}=$ Gentamicin $(10 \mu \mathrm{g}), \mathrm{NA}=$ Nalidixic acid $(30 \mu \mathrm{g})$, $\mathrm{C}=$ Chloramphenicol $\quad(30 \mu \mathrm{g}), \quad \mathrm{SXT}=$ Trimethoprim-sulfamethoxazole $\quad(25 \mu \mathrm{g}), \quad \mathrm{NOR}=$ Norfloxacin $\quad(10 \mu \mathrm{g})$, $\mathrm{E}=$ Erythromycin $(15 \mu \mathrm{g}), \mathrm{R}=$ Resistant.

In this study, the total staphylococcal count ranged from $10 \times 10^{4} \mathrm{CFU} / \mathrm{g}$ to $50 \times 10^{6} \mathrm{CFU} / \mathrm{g}$ (Table 2). The highest staphylococcal count may results from poor hygienic condition of cultivated areas or contamination from respiratory system and body surface of food handlers or by infected workers. Staphylococcus aureus has been reported to remain the most prominent aetiological agent of pyogenic infections and that staphylococcal infection leads 
to a worsening of some already existing superficial infections (Adegoke and Komolafe, 2009). This findings are in agreement with that report Rabbi et al. (2011) who found all food samples including vegetables were contaminated by Staphylococcus spp. The presence of Staphyllococcus spp. $\left(2 \times 10^{5}\right.$ to $\left.5.95 \times 10^{7} \mathrm{CFU} / \mathrm{g}\right)$ has been reported to contaminate some salad vegetables such as carrots, cucumber, tomato and lettuce (Rahman and Noor, 2012).

\subsection{Antimicrobial susceptibility testing}

Antimicrobial susceptibility of 30 isolates of Klebsiella spp. from salad vegetables are presented in Table 3. Figure 1 summarizes the antimicrobial resistance in Klebsiella spp. isolated from salad vegetables.

In this study, the highest $(86.66 \%)$ resistance among Klebsiella spp. was observed to erythromycin. In case of Ceftriaxone and Amoxycillin, 73.33 and $60 \%$ isolates were detected as resistant, respectively. $26.66 \%$
Klebsiella spp. were observed to be resistant and $56.66 \%$ isolates were intermediate to tetracycline. It was observed that, $76.66 \%$ isolates were streptomycin-intermediate and $33.33 \%$ isolates were gentamicin-intermediate. On the other hand, imipenem, ciprofloxacin and norfloxacin were found to be completely sensitive against the Klebsiella isolates tested. The lowest resistance value was figured out as $6.66 \%$ for chloramphenicol, $16.66 \%$ for nalidixic acid and $26.66 \%$ for trimethoprimsulfamethoxazole.

Antibiotic resistance patterns and multidrug resistance pattern for Klebsiella species from salad vegetables are presented in Table 4. Among 30 isolates of the total Klebsiella spp., $90 \%$ isolates displayed multidrug resistance (MDR). Highest number of resistant antibiotics (AML-CRO-TE-E-NA-SXT) was observed to $6.66 \%$ isolates. Multidrug resistance was observed in $98.06 \%$ isolates with resistance to two to seven antibiotics (Nipa et al., 2011).

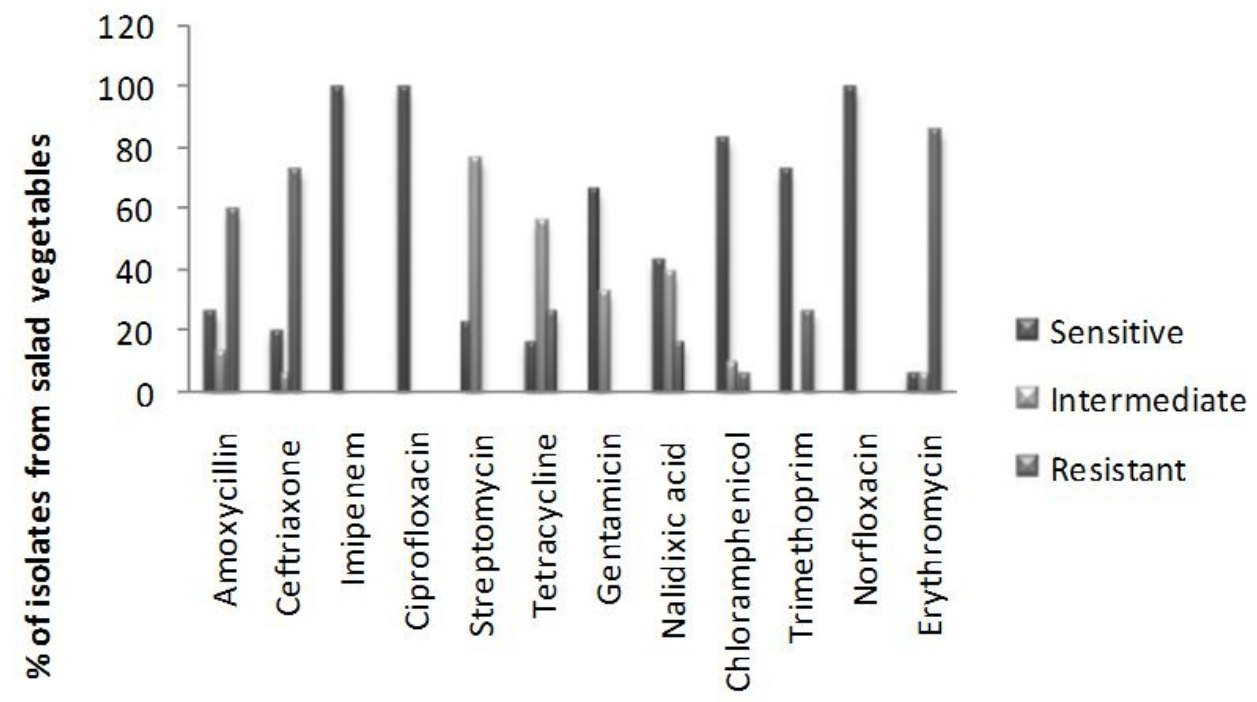

\section{Antibiotics}

Figure 1: Antibiotic sensitivity pattern of Klebsiella spp. isolated from salad vegetables 
Table 4. Antibiotic resistance profiles for Klebsiella species isolated from salad vegetable samples

\begin{tabular}{ccccc}
\hline $\begin{array}{c}\text { No. of } \\
\text { resistant } \\
\text { antibiotics }\end{array}$ & $\begin{array}{c}\text { No. of } \\
\text { isolates }\end{array}$ & Antimicrobial resistance profile & $\%$ & $\begin{array}{c}\text { Resistance } \\
\text { classification }\end{array}$ \\
\hline 6 & 2 & AML-CRO-TE-E-NA-SXT & 6.66 & MDR \\
5 & 1 & AML-CRO-TE-NA-SXT & 3.33 & MDR \\
4 & 5 & AML-CRO-E-TE/SXT & 16.66 & MDR \\
3 & 9 & AML-CRO-E/TE & 30 & MDR \\
2 & 10 & AML-E, CRO-C/E/SXT, E-NA & 33.33 & MDR \\
1 & 3 & E & 10 & NMDR \\
\hline
\end{tabular}

*MDR - Multidrug resistance, NMDR - Non multidrug resistance.

Oluyege et al. (2009) showed $85 \%$ of the resistant isolates were multidrug resistant where highest $(89.1 \%)$ resistance was to the amoxicillin. Adeshina et al. (2012) found some sensitive isolates to amoxicillin, tetracycline and cotrimoxazole; conversely, some were also resistant to gentamicin, nalidixic acid as well as ofloxacin. The highest number of pathogenic bacteria isolated from ready-to-eat fresh vegetables were resistant to penicillin and vancomycin where, the isolates were sensitive to streptomycin and gentamycin (Ali et al., 2011). In general, bacteria can develop resistance for antimicrobial agents, which share similar genetic structures (Angela et al., 2006). Van de Boogard and Stobberingh (2000) reported that due to indiscriminate use of antibiotics, such high incidence of multidrug resistance may apparently be occurred which may ultimately replace the drug sensitive microorganisms from antibiotic saturated environment. Sometimes abuse of antibiotics as well as poor sanitation systems could also play potential roles.

\section{Conclusions}

The high bacterial load and presence of multidrug resistant organisms in the salad vegetable samples could serve as an indicator for the necessity to promote consciousness about the possible health hazards due to poor handling of these vegetables. There is therefore, the necessary for the regulatory authorizations to ensure that the microbiological standards are established and practiced by the farmers and sellers for handling and distribution of salad vegetables.

\section{Acknowledgement}

We would like to thank Nigarin Sultana, Pravas Chandra Roy and Farhana Huqe for their significant guidance and support. This work was financed by Jessore University of Science and Technology, Jessore, Bangladesh.

\section{References}

Adegoke, A. A. and Komolafe. A. O. 2009. Multi-drug resistant Staphylococcus aureus in clinical cases in IIe-Ife, Southest Nigeria. International Journal of Medicine and Medical Sciences. 1(3): 6872.

Angela, L. B., Ian, B. B. and Diana, S. A. 2006. Evaluating the vulnerability of surface waters to antibiotic contamination from varying wastewater treatment plant discharges. Environmental Pollution, 142: 295-302.

Adebayo-Tayo, B. C., Odu, N. N., Esen, C. U. and Okonko, I. O. 2012. Microorganisms associated with spoilage of stored vegetables in Uyo Metropolis, Akwa Ibom State, Nigeria. Nature and Science, 10(3): 23-32. 
Adeshina, G. O., Samuel, D. J. and Victor, E. A. 2012. Antibacterial susceptibility pattern of pathogenic bacteria isolates from vegetable salad sold in restaurants in Zaria, Nigeria. Journal of Microbiology Research, 2(2): 5 -11.

Ali, M., Khan, M. R. and Saha, M. L. 2011. Antibiotic resistant patterns of bacterial isolates from ready-to-eat street vended fresh vegetables and fruits in Dhaka city. Bangladesh Journal of Scientific Research, 24(2): 127-134.

Bauer, A. W., Kirby, W. M. M., Sheries, J. C. and Turek, M. 1966. Antibiotic susceptibility testing by a standardized single disc method. American Journal of Clinical Pathology, 45(4): 493-496.

Gagliardi, J. V. and Karns, J. S. 2000. Leaching of Escherichia coli O157: $\mathrm{H} 7$ in diverse soils under various agricultural management practices. Applied and Environmental Microbiology, 6: 877-883.

Hasan, A., Utku, O. and Koray, K. 2006. Determination of total aerobic and indicator bacteria on some raw eaten vegetables from wholesalers in Ankara, Turkey. International Journal of Hygiene and Environmental Health, 209: 197-201.

Halablab, M. A., Sheet, I. H. and Holail, H. M. 2011. Microbial quality of raw vegetables grown in Bekaa valley, Lebanon. American Journal of Food Technology, 6: 129-139.

Johannessen, G. S., Loncarevic, S. and Kruse, H. 2002. Bacteriological analysis of fresh produce in Norway. International Journal of Food Microbiology, 77: 199-204.

Krieg, N. R. and Holt, J. G. 1984. Bergey's manual of systematic bacteriology, vol. 1. Williams and Wilkins, Baltimore.

Nawas, T., Mazumdar, R. M., Das, S., Nipa, M. N., Islam, S., Bhuiyan, H. R. and Ahmad,
I. 2012. Microbiological quality and antibiogram of E. coli, Salmonella and Vibrio of salad and water from restaurants of Chittagong. Journal of Environmental Science \& Natural Resources, 5(1): 159166.

Nipa, M. N., Mazumdar, R. M., Hasan, M. M., Fakruddin, M., Islam, S., Bhuiyan, H. R. and Iqbal, A. 2011. Prevalence of multi drug resistant bacteria on raw salad vegetables sold in major markets of Chittagong city, Bangladesh. Middle-East Journal of Scientific Research, 10(1): 7077.

Oluyege, A. O., Dada, A. C., Ojo, A. M. and Oluwadare, E. 2009. Antibiotic resistance profile of bacterial isolates from food sold on a University campus in south western Nigeria. African Journal of Biotechnology, 8(21): 883-887.

Olayemi, A. B. 2007. Microbiological hazards associated with agricultural utilization of urban polluted river water. International Journal of Environmental Health Research, 7(2): 149-154.

Osamwonyi, O. U., Obayagbona, O. N., Aborishade, W., Olisaka, F., Uwadiae, E. and Igiehon, O.N. 2013. Bacteriological quality of vegetable salads sold at restaurants within Okada Town, Edo State, Nigeria. African Journal of Basic \& Applied Sciences, 5(1): 37-41.

Osibote, I. A., Okiki, P. A., Ekundayo, E. A. and Adekunle, A. C. 2014. Prevalence of multidrug resistant bacterial isolates from meat processing equipment and abattoir environment in Ado Ekiti. Advances in Biological Research, 8(5): 207-211.

Poorna, V. and Randhir, A. 2001. Prevalence and growth of pathogens on salad vegetables, fruits and sprouts. International Journal of Environmental Hygiene and Health, 203: 205-213. 
Rajvanshi, A. 2010. Bacterial load on street vended salads in Jaipur city, India. Internet Journal of Food Safety, 12: 136139.

Rahman, F. and Noor, R. 2012. Prevalence of pathogenic bacteria in common salad vegetables of Dhaka metropolis. Bangladesh Journal of Botany, 41(2): 159-162.

Rabbi, F. A., Rabbi, F., Runun, T. A., Zaman, K., Rahman, M. M. and Noor, R. 2011. Microbiological quality assessment of foods collected from different hospitals within Dhaka city. Stamford Journal of Microbiology, 1(1): 31-36.
Sultana, F., Kamrunnahar, Afroz, H., Jahan A., Fakruddin, M. and Datta, S. 2014. Multiantibiotic resistant bacteria in frozen food (ready to cook food) of animal origin sold in Dhaka, Bangladesh. Asian Pacific Journal of Tropical Biomedicine, 4(1): 268-271.

Uzeh, R. E., Alade, F. A. and Bankole, M. 2009. The microbial quality of pre packed mixed vegetable salad in some retail outlets in Lagos Nigeria. African Journal of Food Science, 3(9): 270-272.

Van de Boogard, A. E. and Stobberingh, E. E. 2000. Epidemiology of resistance to antibiotics links between animals and humans. International Journal of Antimicrobial Agents, 14: 327-335. 